\title{
Nitrogenous waste excretion by the larvae of a phylogenetically ancient vertebrate: the sea lamprey (Petromyzon marinus)
}

\author{
M.P. Wilkie, Y. Wang, P.J. Walsh, and J.H. Youson
}

\begin{abstract}
Larval sea lampreys (Petromyzon marinus) (ammocoetes) excreted significant quantities of urea, which composed $15-20 \%$ of the total nitrogenous waste excreted. Compared with teleosts of similar size, ammonia and urea excretion rates $\left(J_{\mathrm{Amm}}\right.$ and $J_{\text {Urea }}$, respectively) in ammocoetes were relatively low, reflecting the low metabolic rate of these burrow-dwelling suspension feeders. Analyses of liver enzymes indicated that ammocoetes had all the enzymes necessary to produce urea via uricolysis, but not those of the ornithine-urea cycle (OUC). Further, exposure to $2 \mathrm{mmol} \cdot \mathrm{L}^{-1}$ total ammonia for $5 \mathrm{~d}$ was accompanied by a 3 -fold elevation of $J_{\text {Urea }}$, but did not lead to greater OUC activity. Internal ammonia levels increased markedly, however, exceeding $2000 \mu \mathrm{mol} \cdot \mathrm{L}^{-1}$ in plasma and $5000 \mu \mathrm{mol} \cdot \mathrm{L}^{-1}$ in muscle after the 5-d exposure period. This high resistance to internal ammonia accumulation was related to the very high glutamine synthetase activities measured in ammocoete brains. The excretion and production of urea by ammocoetes demonstrates for the first time that agnathans are capable of producing physiologically relevant amounts of urea. Given the ancient origins and conserved evolution of lampreys, these observations also suggest that at least some of the early jawless vertebrates were able to produce and excrete urea.
\end{abstract}

\begin{abstract}
Résumé : Les larves (ammocètes) de la Lamproie marine (Petromyzon marinus) excrètent des quantités importantes d'urée qui contiennent de 15 à $20 \%$ de tous les déchets azotés excrétés. Comparativement à ceux enregistrés chez des téléostéens de même taille, les taux d'excrétion de l'ammoniaque $\left(J_{\mathrm{Amm}}\right)$ et de l'urée $\left(J_{\text {urée }}\right)$ sont relativement faibles chez les ammocètes, ce qui reflète le faible taux de métabolisme de ces poissons fouisseurs qui se nourrissent de particules en suspension. L'analyse des enzymes du foie indique que les ammocètes possèdent toutes les enzymes nécessaires à la production d'urée par uricolyse, mais n'ont pas de cycle d'ornithine-urée (OUC). En outre, une exposition à $2 \mathrm{mmol} \cdot \mathrm{L}^{-1}$ d'ammoniaque pendant 5 jours résulte en une triplication du taux $J_{\text {urée, }}$ mais ne déclenche pas une plus grande activité du cycle OUC. L'ammoniaque interne augmente cependant fortement, excédant $2000 \mu \mathrm{mol} \cdot \mathrm{L}^{-1}$ dans le plasma et $5000 \mu \mathrm{mol} \cdot \mathrm{L}^{-1}$ dans le muscle après 5 jours d'exposition. La forte résistance à l'accumulation interne d'ammoniaque est reliée à une activité très élevée de la glutamine synthétase dans le cerveau des larves. L'excrétion et la production d'urée chez les ammocètes démontre pour la première fois que les agnathes sont capables de produire des quantités physiologiquement importantes d'urée. Vu les origines reculées et l'évolution conservatrice de la lamproie, il faut conclure d'après ces observations qu'au moins certains vertébrés agnathes primitifs étaient capables de synthétiser et d'excréter de l'urée.
\end{abstract}

[Traduit par la Rédaction]

\section{Introduction}

In vertebrates, urea is produced by either the ornithineurea cycle (OUC) or uricolysis, or through the degradation of dietary arginine (for reviews see Mommsen and Walsh 1991; Anderson 1995). In mammals and amphibians, urea production by the OUC is associated with water conservation and the prevention of ammonia toxicity (Wright 1995).

Received August 28, 1998. Accepted January 19, 1999.

M.P. Wilkie. ${ }^{1}$ Department of Biology, Mount Allison University, Sackville, NB E4L 1G7, Canada.

Y. Wang and P.J. Walsh. Division of Fisheries and Marine

Biology, Rosenstiel School of Marine and Atmospheric

Science, University of Miami, Miami, FL 33149-1098, U.S.A.

J.H. Youson. Division of Life Sciences, University of

Toronto at Scarborough, Scarborough, ON M1C 1A4,

Canada.

${ }^{1}$ Author to whom all correspondence should be addressed

(e-mail: mwilkie@mta.ca).
Elasmobranches, holocephalans, and the coelacanth (Latimeria chalumnae) also use the OUC, but they retain urea as an osmolyte in their marine environments (Mommsen and Walsh 1989). Most teleosts produce urea via uricolysis, in which uric acid arising from purine degradation is converted to urea (Florkin and Duchâteau 1943; Goldstein and Forster 1965; Cvancara 1969). Certain fishes, however, rely on urea production and excretion because they are subject to environmental constraints that impair ammonia excretion, such as periodic air exposure (Saha and Ratha 1989) or life in alkaline environments (Randall et al. 1989). In these unusual instances, most urea is produced via the OUC.

Although the expression of key OUC enzymes is rare in teleosts, its presence in this group, and in elasmobranchs, the coelacanth, lungfishes, amphibians, and mammals, has led to the proposal that the OUC is a monophyletic trait in the vertebrate lineage (Mommsen and Walsh 1989, 1991). Indeed, the possibility that the earliest vertebrates had a full complement of OUC enzymes has been proposed by Brown and Brown (1985) and Griffith (1991). This hypothesis can be 
examined further by studying nitrogenous waste production and excretion patterns in extant members of the superclass Agnatha. These ancient jawless vertebrates are represented by the present-day hagfishes (class Myxini) and lampreys (class Cephalaspidomorphi).

Despite their ancient phylogenetic lineage, there is a gap in our understanding about how nitrogenous wastes are produced and excreted by agnathans. Studies on hagfishes indicate that significant amounts of urea are present in hagfish plasma (Bdellostoma cirrhatum; Robertson 1954), but key uricolytic and OUC enzymes are absent (Read 1975). The one reported study of the Pacific lamprey (Entosphenus tridentatus) indicates that urea composes less than $1 \%$ of the total nitrogen excreted by this animal, and enzymatic analyses suggest that it arises from the breakdown of endogenous arginine stores, not from the OUC (Read 1968). The lack of uricolytic enzyme activity in the liver of river lampreys (Lampetra fluviatilis; Florkin and Duchâteau 1943) suggests that urea is unlikely to be produced via uricolysis in lampreys. Notably, these earlier studies focused on adult lampreys, yet most of the lamprey's life is spent as a larva (ammocoete).

For the first 3-7 years of their life cycle, sea lamprey (Petromyzon marinus) ammocoetes live burrowed in the substrate of freshwater streams as relatively sedentary suspension feeders (Youson 1980) and their primary diet is detritus (Sutton and Bowen 1994). This larval growth phase is followed by a complex metamorphosis, characterized by pronounced changes in internal and external body structure and metabolism. Following metamorphosis, the juvenile sea lampreys migrate downstream to freshwater lakes or marine environments where they parasitize primarily teleost fishes. After 1-2 years, the adults stop feeding, commence a final sexual maturation during an upstream migration, spawn, and then die (Youson 1980).

Since the life cycle of the sea lamprey is characterized by profound changes in body structure, habitat, activity level, and diet, we predicted that patterns of nitrogenous waste metabolism would reflect the lamprey's stage of development. Accordingly, the present study was designed to test the hypothesis that, unlike adult lampreys (cf. Read 1968), ammocoetes produce and excrete physiologically relevant amounts of urea. Consequently, the rates of ammonia excretion $\left(J_{\text {Amm }}\right)$ and urea excretion $\left(J_{\text {Urea }}\right)$ were measured in sea lamprey ammocoetes ( $P$. marinus) and, in addition, the activities of key enzymes of the OUC and uricolytic pathways were measured in the liver. Since accumulation of internal ammonia is known to stimulate urea production in some teleosts (Walsh et al. 1990; Saha and Ratha 1994), subsets of ammocoetes were also exposed to high external levels of ammonia to determine if their reliance on urea production increased when ammonia excretion was inhibited.

\section{Materials and methods}

\section{Experimental animals and setup}

Landlocked larval (ammocoetes) sea lampreys ( $P$. marinus) weighing 2-3 g were collected from Putnam Creek, New York (Lake Champlain), and the Platte River, Michigan (Great Lakes), in the summers of 1995 and 1997, using Pulsed DC electrofishing (Smith Root Model 12). They were transported to the University of Toronto at Scarborough in insulated containers and held in aerated
500-L Living Streams (Frigid Units, Ohio), receiving dechlorinated tap water $\left(T=8-12^{\circ} \mathrm{C}\right.$; hardness $=1.4 \mathrm{mEq}$ as $\left.\mathrm{CaCO}_{3} ; \mathrm{pH}=7.9\right)$ on a continuous basis $\left(200-400 \mathrm{~mL} \cdot \mathrm{min}^{-1}\right)$. Petromyzon marinus ammocoetes were also collected, in an identical manner, from the Buctouche River, New Brunswick, in the fall of 1996. These animals, which represented the anadromous sea lamprey population indigenous to the Canadian Atlantic Provinces, were kept in 200-L holding containers at Mount Allison University and received well water $\left(T=11^{\circ} \mathrm{C}\right.$; hardness $=4.0 \mathrm{mEq}$ as $\left.\mathrm{CaCO}_{3} ; \mathrm{pH}=7.6\right)$ on a continuous basis $\left(400 \mathrm{~mL} \cdot \mathrm{min}^{-1}\right)$. After transport, all animals quickly burrowed into the sandy substrate that lined their holding containers. In each case, ammocoetes were maintained in accordance with the Canadian Council on Animal Care guidelines.

Since feeding markedly influences patterns of nitrogenous waste production and excretion in fishes (e.g., Wright 1993), 7-10 d before experiments, subsets of ammocoetes $(n=20-25)$ were transferred to 10 - to $25-\mathrm{L}$ isolation aquaria $\left(T=15^{\circ} \mathrm{C}\right)$ that contained clean silica sand as burrowing substrate. This precaution ensured that the ammocoetes did not feed on detrital biofilm, their primary food source (Sutton and Bowen 1994), which could accumulate in their original holding tanks after their weekly feeding with a yeast slurry (approximately 2 g yeast per ammocoete; Holmes and Youson 1994).

\section{Experimental protocol}

\section{Series I: Basal nitrogenous waste excretion patterns}

Nitrogenous waste excretion rates were determined in landlocked ammocoetes collected from Putnam Creek and in ammocoetes of the anadromous population from New Brunswick. In these experiments, animals were weighed one at a time and then transferred to modified 100 - to $200-\mathrm{mL}$ specimen containers that served as individual flux chambers for excretion rate determinations. The well-aerated darkened flux chambers received water at a flow rate of $50 \mathrm{~mL} \cdot \mathrm{min}^{-1}$.

Nitrogenous waste excretion rates were measured over $12-24 \mathrm{~h}$ to determine if basal $J_{\mathrm{Amm}}$ and $J_{\text {Urea }}$ fluctuated diurnally. $\mathrm{J}_{\mathrm{Amm}}$ and $J_{\text {Urea }}$ were determined during separate 4 -h periods. These 4-h measurement periods (termed a flux) were initiated by shutting off water flow to each chamber and then adjusting the water volume in the chamber to $70 \mathrm{~mL}$. Subsequently, $10-\mathrm{mL}$ water samples were withdrawn after 0,2 , and $4 \mathrm{~h}$, via an externally mounted sampling port. Following each flux-determination period, water flow was temporarily reestablished to each chamber before initiating another flux. Water samples were then stored at $-20^{\circ} \mathrm{C}$.

\section{Series II: Nitrogenous waste excretion during exposure to high external levels of ammonia}

These experiments tested the hypothesis that an ammocoete's reliance on urea excretion and production could be stimulated when ammonia excretion was inhibited. Preliminary bioassay experiments using $\mathrm{NH}_{4} \mathrm{Cl}$ and $\left(\mathrm{NH}_{4}\right)_{2} \mathrm{SO}_{4}$ were conducted to determine the range of ammonia concentrations that could be tolerated by ammocoetes. Accordingly, groups of landlocked ammocoetes $(n=12)$ were exposed to $0,1,2,4,8,16$, or $32 \mathrm{mmol} \cdot \mathrm{L}^{-1}$ total ammonia (the sum of $\left[\mathrm{NH}_{4}^{+}\right]+\left[\mathrm{NH}_{3}\right]$ ). Based on the observed survival over $96 \mathrm{~h}$, the $\mathrm{LC}_{50}$ values for total ammonia and $\mathrm{NH}_{3}$ were determined using log-probit analyses (Sprague 1969).

Nitrogenous waste excretion rates were subsequently determined in landlocked (Putnam Creek) ammocoetes, under control conditions and after $0-1,1-4,8-12,24,48,72,96$, and $120 \mathrm{~h}$ of exposure to high external levels of ammonia $\left(2 \mathrm{mmol} \cdot \mathrm{L}^{-1}\right.$ total ammonia). Determinations made on control animals (no exposure to high external levels of ammonia) were made simultaneouly with those made on the experimental animals. An additional group was exposed to $1 \mathrm{mmol} \cdot \mathrm{L}^{-1}$ total ammonia but, for this group, only the plasma ammonia and urea concentrations are reported. 
To ensure that external ammonia concentrations were not altered as a result of excretion by the animals or volatilization to the atmosphere, water in the chambers was changed daily. Owing to the low nitrogenous waste excretion rates of these animals, more frequent replacement of the water was unnecessary. Average total ammonia concentrations in the control containers were less than $25 \mu \mathrm{mol} \cdot \mathrm{L}^{-1}$, while average concentrations in the ammonia-treatment containers were $0.99 \pm 0.06$ and $1.97 \pm 0.01 \mathrm{mmol} \cdot \mathrm{L}^{-1}$ at nominal total ammonia concentrations of 1 and $2 \mathrm{mmol} \cdot \mathrm{L}^{-1}$, respectively.

At the completion of the final flux determination periods, the ammocoetes were killed one at a time with an overdose $\left(3 \mathrm{~g} \cdot \mathrm{L}^{-1}\right)$ of tricaine methane sulfonate (Syndel Laboratories, Vancouver, B.C.) buffered with $\mathrm{NaHCO}_{3}\left(6 \mathrm{~g} \cdot \mathrm{L}^{-1}\right)$. Blood samples were collected from the heart into nonheparinized capillary tubes by making an incision behind the last branchiopore. The capillary tubes were centrifuged at $5000 \times g$ for $3 \mathrm{~min}$, and the haematocrit was determined. Each tube was then fractured just above the red blood cell pellet and the plasma dispensed into 0.5-mL Eppendorf centrifuge tubes, frozen in liquid nitrogen, and stored at $-70^{\circ} \mathrm{C}$ for later determination of plasma ammonia, urea, lactate, and glucose.

\section{Series III: Nitrogenous waste production, storage, and detoxification}

Experiments were conducted on landlocked sea lamprey ammocoetes (Platte River) to determine if patterns of internal nitrogenous waste production and storage were altered by high ambient levels of ammonia. Excretion rates were not determined in these experiments. Instead, the ammocoetes were held in groups of 5 or 6 in $1.5-\mathrm{L}$ elongated chambers containing $1.0 \mathrm{~L}$ of water $\left(15^{\circ} \mathrm{C}\right)$ and aquarium cotton, which served as burrowing substrate. Ammocoetes were held under control conditions or exposed to high external levels of ammonia $\left(2 \mathrm{mmol} \cdot \mathrm{L}^{-1}\right)$ for $5 \mathrm{~d}$ prior to tissue and blood sampling. Mean total ammonia concentrations in water during this experiment were $26 \pm 5 \mu \mathrm{mol} \cdot \mathrm{L}^{-1}$ under control conditions and $2.06 \pm 0.02 \mathrm{mmol} \cdot \mathrm{L}^{-1}$ under experimental conditions.

The ammocoetes were lightly anaesthetized initially (for no more than $15 \mathrm{~min}$, with $0.5 \mathrm{~g} \cdot \mathrm{L}^{-1}$ of buffered tricaine methanesulfonate), before being transferred to a lethal dose of anaesthetic immediately prior to sampling. Light anaesthesia was required to minimize struggling by the ammocoetes, as struggling is known to alter internal ammonia stores in fishes (e.g., Wright and Wood 1988). Following the collection of blood, which generally took 30 $60 \mathrm{~s}$, an incision was made down the midventral line to expose the liver, which was quickly removed, transferred to a $0.5-\mathrm{mL}$ centrifuge tube, and frozen in liquid nitrogen. Livers were stored at $-70^{\circ} \mathrm{C}$ until analysed for OUC, uricolytic, and other related enzyme activities.

As the liver was being collected, the brain and intestines were dissected from each animal and frozen in liquid nitrogen for later analysis of glutamine synthetase (GS) and glutamate dehydrogenase (GDH) activity. The skin was then peeled from the animal's trunk and the region immediately behind the cloaca severed and rapidly frozen in liquid nitrogen with precooled stainless-steel tongs (freeze-clamping) for later determination of GDH and GS activity and muscle ammonia, urea, and glutamine concentrations. Dissections of the postcloacal tail indicated that more than $90 \%$ of this region's wet mass was muscle, the remainder being composed of cartilage, notochord, and blood vessels.

\section{Analytical techniques}

\section{Nitrogenous waste and metabolite analyses}

Measurements of $\mathrm{J}_{\mathrm{Amm}}$ and $J_{\text {Urea }}$ were based on changes in the respective concentrations of each waste product that appeared in the water over each flux determination period, after correcting for the animal's mass and the volume of water in the chamber (e.g., Wilkie and Wood 1991). Total ammonia and urea concentrations in the water were determined as described by Wilkie et al. (1996). Plasma ammonia was determined enzymatically (GDH), using a commercial kit (Sigma). A similar procedure was used to measure ammonia concentrations in muscle extracts, which were prepared according to Wilkie and Wood (1995). Urea concentrations in plasma and muscle extracts were measured using the diacetyl monoxime assay (Crocker 1967), following deproteinization of the samples with an equal volume of $8 \%$ perchloric acid to prevent precipitates from forming in the assay mixture. Muscle glutamine concentrations were measured using GS, as outlined by Mecke (1985). Plasma glucose and lactate concentrations were determined using hexokinase and lactate dehydrogenase, respectively (Bergmeyer 1983).

\section{Enzyme activity determinations}

The tissue homogenization procedures used are described in Walsh (1996), and established methodology was used to determine OUC (Mommsen and Walsh 1989; Barber and Walsh 1993) and uricolytic (Wilkie et al. 1993; Wright 1993) enzyme activities. It should be noted that the activity of the key OUC enzyme, carbamoyl phosphate synthetase III (CPSase III), was measured in the presence of uridine triphosphate to inhibit CPSase II activity, which could interfere with CPSase III activity determinations (see Anderson 1995). Methods used to determine GS (Walsh 1996) and GDH (Barber and Walsh 1993) activity in the liver, brain, intestine, and muscle are also described elsewhere. All enzyme activities are expressed as micromoles of product formed per gram of wet tissue per minute at $20^{\circ} \mathrm{C}$.

Since the gulf toadfish (Opsanus beta) has a full complement of OUC enzymes (Mommsen and Walsh 1989), this animal served as a positive control for the measurement of OUC and related enzyme activities. The gulf toadfish also served as a positive control for the determination of uricolytic enzyme activity levels, because this pathway is active in most teleosts (e.g., Goldstein and Forster 1965). In all cases, the livers from 2-3 individual gulf toadfish (captured by roller trawl in Biscayne Bay, Fla.) were homogenized and subsequently assayed in a manner identical to the samples from the ammocoetes. Prior to making enzyme activity measurements, the optimal assay conditions for lamprey tissues were determined and found to be similar to those used for the gulf toadfish.

\section{Statistics}

All data are expressed as the mean \pm 1 standard error of the mean (SEM). Sample numbers $(N)$ represent measurements made on individual animals, except in the case of enzymatic determinations on liver and brain samples. Owing to the small size of ammocoete livers (5-20 mg each) and brains (<5 mg each), samples were pooled to ensure that there was sufficient tissue for determining enzyme activities. In these cases, $N$ is the number of livers or brains in the pooled sample (4-8 livers or brains per pooled sample). Unpaired data were analysed using one-way analysis of variance (ANOVA), and paired data were analysed using repeatedmeasures ANOVA. When significant variability was observed, statistical significance between means was assessed using the TukeyKramer post-test at the $P<0.05$ level. When the requirement for homogeneity of variance was not satisfied, samples were analysed using nonparametric ANOVAs, followed by Dunn's post-test. All statistical analyses were conducting using commercial software (Instat, Graphpad Inc., San Diego).

\section{Results}

\section{Series I: Basal nitrogenous waste excretion patterns}

Over a continuous 1 -d sampling regime $J_{\mathrm{Amm}}$ and $J_{\text {Urea }}$ for landlocked sea lampreys exhibited no apparent diurnal fluctuations (Fig. 1A). Basal $J_{\mathrm{Amm}}$ fluctuated around $50 \mathrm{nmol} \mathrm{N} \cdot \mathrm{g}^{-1} \cdot \mathrm{h}^{-1}$ and composed about $85 \%$ of the total ni- 
Fig. 1. Mean ammonia and urea excretion rates $\left(J_{\mathrm{Amm}}\right.$ (solid bars) and $J_{\text {Urea }}$ (hatched bars), respectively) of (A) landlocked ammocoetes $(N=14)$ and (B) ammocoetes representing anadromous sea lamprey populations from New Brunswick $(N=$ 8). The percent contribution of each nitrogenous waste product to the total nitrogenous waste excretion rate $\left(J_{\mathrm{N} \text {-waste }}=J_{\mathrm{Amm}}+\right.$ $J_{\text {Urea }}$ ) is indicated above each bar; $J_{\text {Amm }}$ and $J_{\text {Urea }}$ did not change significantly during either experiment.
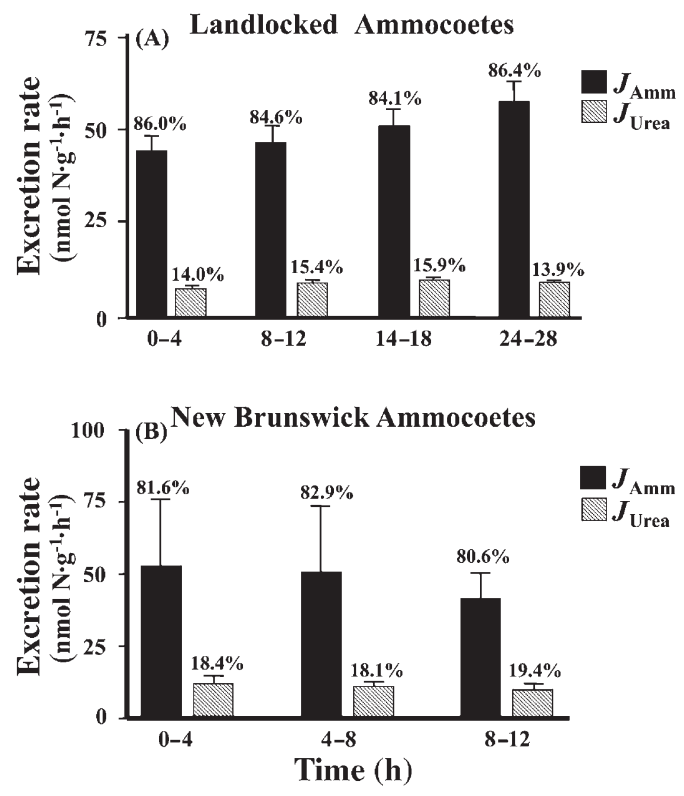

trogenous waste excreted $\left(J_{\mathrm{N} \text {-waste }}=J_{\text {Amm }}+J_{\text {Urea }}\right)$. $J_{\text {Urea }}$ averaged $10 \mathrm{nmol} \mathrm{N} \cdot \mathrm{g}^{-1} \cdot \mathrm{h}^{-1}$, accounting for about $15 \%$ of the total nitrogenous waste excreted (Fig. 1A). In the New Brunswick ammocoetes, which represent an anadromous sea lamprey population, comparable results were observed, with $J_{\text {Amm }}$ and $J_{\text {Urea }}$ approximating levels measured in the landlocked ammocoetes (Fig. 1B). Notably, $J_{\text {Urea }}$ was quite variable in both populations and, in several animals, comprised more than $30 \%$ of the total nitrogenous waste excreted.

\section{Series II: Nitrogenous waste excretion during exposure to high external levels of ammonia}

The 96-h $\mathrm{LC}_{50}$ values for ammonia were determined for landlocked ammocoetes in separate sets of experiments, one set using $\mathrm{NH}_{4} \mathrm{Cl}$ and one using $\left(\mathrm{NH}_{4}\right)_{2} \mathrm{SO}_{4}$. In each case the $\mathrm{LC}_{50}$ for total ammonia was $3 \mathrm{mmol} \cdot \mathrm{L}^{-1}$, which is equal to a 96-h $\mathrm{LC}_{50}$ for $\mathrm{NH}_{3}$ of $100 \mu \mathrm{mol} \cdot \mathrm{L}^{-1}$ (data not shown). In both sets of experiments, water temperature was $15^{\circ} \mathrm{C}, \mathrm{pH}$ averaged 8.0, and water hardness was $1.4 \mathrm{mEq}$ as $\mathrm{CaCO}_{3}$.

Exposure to high external levels of ammonia led to net uptake of total ammonia by the ammocoetes that exceeded $-1000 \mathrm{nmol} \cdot \mathrm{g}^{-1} \cdot \mathrm{h}^{-1}$ during the first hour. However, $J_{\mathrm{Amm}}$ gradually recovered and by $24-48 \mathrm{~h}$ it had returned to control-rate levels (Fig. 2). In the control animals tested simultaneously, no significant variation was observed in $J_{\mathrm{Amm}}$ over the first $48 \mathrm{~h}$ of the experiment, during which period $J_{\text {Amm }}$ averaged $40-50 \mathrm{nmol} \cdot \mathrm{g}^{-1} \cdot \mathrm{h}^{-1}$. However, from 72 to $120 \mathrm{~h}, J_{\mathrm{Amm}}$ was 2 -fold higher in the control animals (data not shown).

Although $J_{\text {Urea }}$ increased 3-fold during exposure to high external levels of ammonia, these significant increases only took place after $J_{\mathrm{Amm}}$ had recovered to pre-exposure rates
Fig. 2. The influence of 120-h exposure to high external levels of ammonia ( $2 \mathrm{mmol} \cdot \mathrm{L}^{-1}$ total ammonia) on ammonia excretion $\left(J_{\text {Amm }}\right)$ by individual ammocoetes $(N=14)$. Positive values indicate excretion, while negative values indicate net ammonia uptake. An asterisk indicates a statistically significant difference from pre-exposure $(C) J_{\mathrm{Amm}}(P<0.05)$.

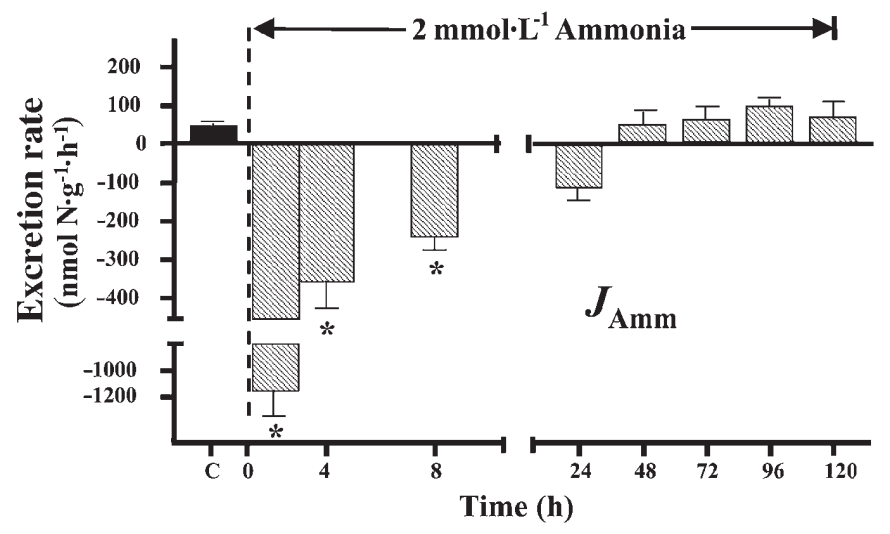

Fig. 3. The influence of high external levels of ammonia $\left(2 \mathrm{mmol} \cdot \mathrm{L}^{-1}\right.$ total ammonia) on urea excretion $\left(J_{\text {Urea }}\right)$ by ammocoetes. Controls are represented by solid bars $(N=12)$ and animals subjected to high external levels of ammonia are represented by hatched bars $(N=14)$. An asterisk indicates significant differences from pre-exposure $J_{\text {Urea }}$; a dagger indicates significant differences from simultaneously tested controls $(P<$ 0.05 ); C, pre-exposure $J_{\text {Urea }}$.

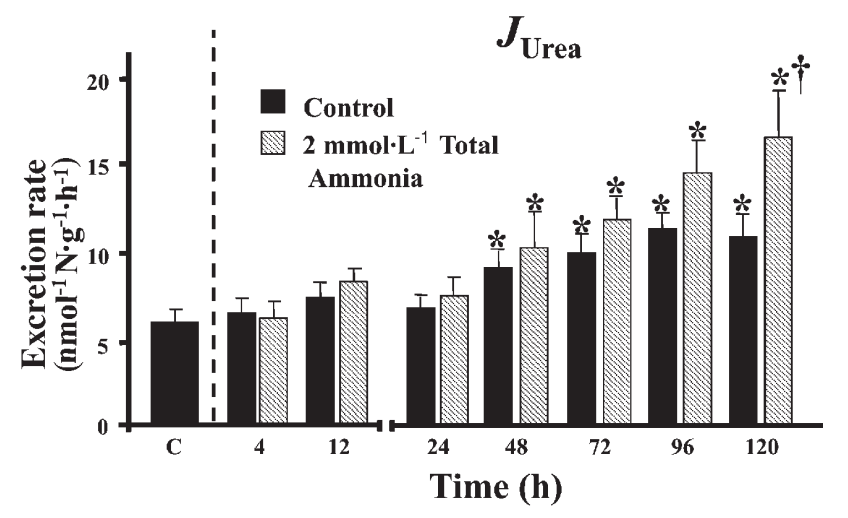

(Fig. 3). Moreover, as with $J_{\mathrm{Amm}}, J_{\text {Urea }}$ in the simultaneously tested control animals also demonstrated an upward trend over the course of the experiment, and $J_{\text {Urea }}$ was only significantly different from rates in the simultaneously tested control animals after $120 \mathrm{~h}$ of exposure to $2 \mathrm{mmol} \cdot \mathrm{L}^{-1}$ total ammonia (Fig. 3).

\section{Series III: Nitrogenous waste production, storage, and detoxification}

The activities of key OUC enzymes in ammocoetes were either very low compared with those for the gulf toadfish or were below the level of detection (Table 1). However, the three uricolytic enzymes were detected and had activities comparable to those measured in gulf toadfish liver (Table 2). With the exception of a 2-fold elevation in liver arginase activity, high external levels of ammonia did not 
Table 1. Activities of enzymes of the ornithine-urea cycle and of glutamine synthetase $\left(\mu \mathrm{mol}\right.$ product $\cdot \mathrm{g}^{-1} \cdot \mathrm{min}^{-1}$ ) in the livers of ammocoetes under control conditions and after exposure to high external levels of total ammonia $\left(2 \mathrm{mmol} \cdot \mathrm{L}^{-1}\right)$.

\begin{tabular}{lllr}
\hline Enzyme & Control & $\begin{array}{l}\text { High external } \\
\text { ammonia level }\end{array}$ & \multicolumn{1}{c}{ O. beta } \\
\hline Carbamoyl phosphate synthetase III & BD & BD & $0.14 \pm 0.04(5)$ \\
Ornithine carbamoyl transferase & $0.09 \pm 0.01(6)$ & $0.06 \pm 0.01(5)$ & $20.70 \pm 2.60(5)$ \\
Argininosuccinate synthetase-lyase & $0.04 \pm 0.01(6)$ & $0.02 \pm 0.01(5)$ & $0.31 \pm 0.04(9)$ \\
Arginase & $0.56 \pm 0.05(6)$ & $1.10 \pm 0.20^{*}(5)$ & $21.10 \pm 0.86(2)$ \\
Glutamine synthetase & $0.27 \pm 0.05(7)$ & $0.40 \pm 0.04(6)$ & $2.84 \pm 0.38(4)$ \\
\hline
\end{tabular}

Note: Values in parentheses show the number of pooled samples analysed. Each pooled sample was composed of livers from 4-6 individual ammocoetes. BD, below detection limit (level of detection for CPSase III = approximately $0.01-0.02 \mu \mathrm{mol}$ product formed $\cdot \mathrm{g}^{-1}$ wet tissue $\left.\cdot \mathrm{min}^{-1}\right)$.

${ }^{a}$ Positive control.

*Significantly different statistically from control value.

Table 2. Uricolytic enzyme activity $\left(\mu \mathrm{mol}\right.$ product $\left.\cdot \mathrm{g}^{-1} \cdot \mathrm{min}^{-1}\right)$ in the liver of ammocoetes (P. marinus), O. beta, and $O$. niloticus.

\begin{tabular}{llll}
\hline Enzyme & Ammocoete & O. beta $^{a}$ & O. niloticus $^{b}$ \\
\hline Uricase & $0.18 \pm 0.07(5)$ & $0.21 \pm 0.04(2)$ & $0.54 \pm 0.01$ \\
Allantoinase & $0.03 \pm 0.00(9)$ & $0.09 \pm 0.01(4)$ & $0.28 \pm 0.04$ \\
Allantoicase & $0.35 \pm 0.04(6)$ & $0.27 \pm 0.03(2)$ & $0.58 \pm 0.07$ \\
\hline
\end{tabular}

Note: Values in parentheses are the number of pooled samples analysed. Each pooled sample was composed of liver samples from 4 or 5 different ammocoetes.

${ }^{a}$ Positive control

${ }^{b}$ Data from Wright (1993).

lead to detectable changes in the activities of the OUC enzymes (Table 1).

Exposure to high external levels of ammonia had a pronounced affect on internal ammonia concentrations, however. Under control conditions, plasma total ammonia concentrations averaged $400 \mu \mathrm{mol} \cdot \mathrm{L}^{-1}$ but, after $5 \mathrm{~d}$ of exposure to high external levels of ammonia, the concentrations rose significantly to 1200 and $2000 \mu \mathrm{mol} \cdot \mathrm{L}^{-1}$ at 1 and $2 \mathrm{mmol} \cdot \mathrm{L}^{-1}$ total ammonia, respectively (Fig. 4A). Plasma urea concentrations, which ranged from 300 to $400 \mu \mathrm{mol} \cdot \mathrm{L}^{-1}$, were not altered by exposure to either 1 or $2 \mathrm{mmol} \cdot \mathrm{L}^{-1}$ total ammonia (Fig. 4A). A similar trend was observed in muscle, where ammonia concentrations increased from $1000 \mu \mathrm{mol} \cdot \mathrm{L}^{-1}$ in control ammocoetes to more than $5000 \mu \mathrm{mol} \cdot \mathrm{L}^{-1}$ in animals exposed to $2 \mathrm{mmol} \cdot \mathrm{L}^{-1}$ total ammonia (Fig. 4B). Urea concentrations, which were between 600 and $1000 \mu \mathrm{mol} \cdot \mathrm{L}^{-1}$ for both groups, and glutamine concentrations, which averaged 2.6 and $2.8 \mathrm{mmol} \cdot \mathrm{L}^{-1}$ in control and treatment groups, respectively, were not significantly altered in the muscle by exposure to high external levels of ammonia (Fig. 4B).

Ammocoete behaviour was not visibly affected by high external levels of ammonia; at all times animals rested quietly on the bottom of their respective flux chambers. Exposure to $2 \mathrm{mmol} \cdot \mathrm{L}^{-1}$ total ammonia did lead to increased blood haematocrit, however, which was $31 \%$ in control animals but significantly greater, $35 \%$, in treated animals. No significant changes were observed in plasma lactate and glucose concentrations following exposure to the high external levels of ammonia (Table 3).

In control animals, GDH activity was highest in the liver, followed by the muscle, brain, and intestine, but exposure to high external levels of ammonia did not significantly influ-
Fig. 4. (A) Nitrogenous waste (N-waste) concentrations in the plasma of ammocoetes under control conditions $(N=27-30$; solid bars) or following $5 \mathrm{~d}$ of exposure to $1 \mathrm{mmol} \cdot \mathrm{L}^{-1}$ total ammonia $(N=10$ or 11 ; open bars $)$ or $2 \mathrm{mmol} \cdot \mathrm{L}^{-1}$ total ammonia $(N=21-33$; hatched bars). (B) Nitrogenous waste concentrations in the muscle of ammocoetes under control conditions ( $N=7$; solid bars) or following $5 \mathrm{~d}$ of exposure to $2 \mathrm{mmol} \cdot \mathrm{L}^{-1}$ total ammonia $(N=6$ or 7 ; hatched bars). An asterisk indicates statistically significant differences $(P<0.05)$ from nitrogenous waste concentrations in controls.
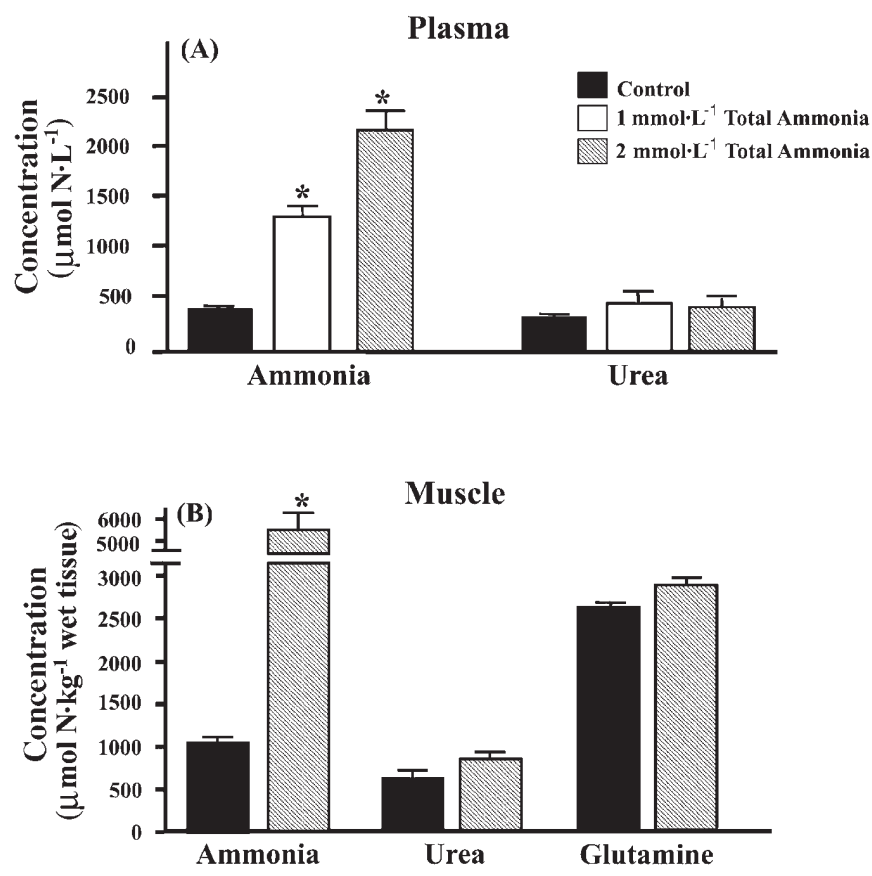

ence GDH enzyme activity in any of these tissues (Table 4). In contrast with GDH, GS activity was 1-2 orders of magnitude higher in the ammocoete brain than in intestine, liver, or muscle (Table 4). Relative to control ammocoetes, brain GS activity increased by $15 \%$ in ammocoetes exposed to $2 \mathrm{mmol} \cdot \mathrm{L}^{-1}$ total ammonia. In addition, GS activity in muscle and intestine was 2- to 3-fold greater in animals subjected to high external levels of ammonia (Table 4). 
Table 3. Selected blood variables measured in ammocoetes under control conditions and after exposure to high external levels of total ammonia $\left(2 \mathrm{mmol} \cdot \mathrm{L}^{-1}\right)$.

\begin{tabular}{llll}
\hline Treatment & $\begin{array}{l}\text { Haematocrit } \\
(\%)\end{array}$ & $\begin{array}{l}\text { Blood lactate } \\
\left(\mathrm{mmol} \cdot \mathrm{L}^{-1}\right)\end{array}$ & $\begin{array}{l}\text { Blood glucose } \\
\left(\mathrm{mmol} \cdot \mathrm{L}^{-1}\right)\end{array}$ \\
\hline Control & $30.8 \pm 1.2(35)$ & $0.13 \pm 0.09(8)$ & $2.0 \pm 0.3(12)$ \\
$1 \mathrm{mmol} \cdot \mathrm{L}^{-1}$ ammonia & $34.4 \pm 1.0(11)$ & $0.24 \pm 0.06(5)$ & $1.4 \pm 0.2(11)$ \\
$2 \mathrm{mmol} \cdot \mathrm{L}^{-1}$ ammonia & $35.1 \pm 0.6^{*}(40)$ & $0.36 \pm 0.14(7)$ & $1.6 \pm 0.2(11)$ \\
\hline
\end{tabular}

Note: Values in parentheses are the number of samples analysed.

*Significantly different from control $(P<0.05)$.

Table 4. The activities of glutamate dehydrogenase and glutamine synthetase $\left(\mu \mathrm{mol}\right.$ product $\left.\cdot \mathrm{g}^{-1} \cdot \mathrm{min}^{-1}\right)$ in tissues of ammocoetes under control conditions and after exposure to high external levels of ammonia $\left(2 \mathrm{mmol} \cdot \mathrm{L}^{-1}\right)$.

\begin{tabular}{lll}
\hline & Control & $\begin{array}{l}\text { High external } \\
\text { ammonia level }\end{array}$ \\
\hline Glutamate dehydrogenase & & \\
$\quad$ Brain & $1.47 \pm 0.20(4)$ & $1.43 \pm 0.10(5)$ \\
Liver & $3.90 \pm 0.29(7)$ & $2.49 \pm 0.23(5)$ \\
Intestine & $1.00 \pm 0.03(8)$ & $1.00 \pm 0.04(6)$ \\
Muscle & $3.29 \pm 0.71(8)$ & $3.05 \pm 0.13(8)$ \\
Glutamine synthetase & & \\
Brain & $53.7 \pm 2.10(8)$ & $61.8 \pm 2.20 *(8)$ \\
Liver & $0.27 \pm 0.05(7)$ & $0.40 \pm 0.04(6)$ \\
Intestine & $0.34 \pm 0.09(8)$ & $1.16 \pm 0.06 *(6)$ \\
Muscle & $0.80 \pm 0.07(8)$ & $1.43 \pm 0.15 *(8)$ \\
\hline
\end{tabular}

Note: Values in parentheses are the number of pooled or unpooled samples. Brain- and liver-enzyme activities were based on data from pooled samples comprising from 4-8 brains or livers, respectively. Intestine- and muscle-enzyme measurements were made on individual tissue samples from single animals (unpooled).

*Significantly different from control $(P<0.05)$.

\section{Discussion}

\section{Patterns of nitrogenous waste excretion}

Ammocoetes produce and excrete significant quantities of urea. On average, 15-20\% of total nitrogenous waste is excreted in this form by both landlocked and anadromous (the New Brunswick population) sea lampreys. The fact that urea comprised more than $30 \%$ of the total nitrogenous wastes excreted by some ammocoetes underscores the lamprey's ability to produce urea. The significant urea levels in the plasma and muscle also provide evidence for urea synthesis by ammocoetes. These observations contrast earlier findings by Read (1968), who reported only trace levels of urea in the urine of adult Pacific lamprey, in which urea composed less than $1 \%$ of the total nitrogenous waste excreted. Further, Robertson (1954) detected no urea in the plasma of the river lamprey. Interspecific differences may account for these apparent discrepancies, but this seems unlikely, because we also detected significant urea excretion by larval American brook lamprey (Lampetra appendix; M.P. Wilkie and J.H. Youson, unpublished observations), a nonparasitic species. A more plausible explanation is that Read's (1968) studies focused on adult lampreys, whose body structure, diet, activity level, and habitat differ from those of ammocoetes. Ammocoetes live burrowed in the substrate of streams as relatively sedentary suspension feeders (Sutton and Bowen
1994), while parasitic and adult lampreys are in a free-swimming and highly active stage of their life cycle (Youson 1980).

The percentage of nitrogenous waste excreted as urea (i.e., 15-20\%) by ammocoetes was comparable with relative levels excreted by many freshwater teleosts, such as carp (Cyprinus carpio; Smith 1929), goldfish (Carassius auratus; Smith 1929), rainbow trout (Wilkie and Wood 1991), and tilapia (Oreochromis niloticus; Wright 1993). However, absolute rates of urea and ammonia excretion by ammocoetes were notably lower than rates reported for other fishes of comparable size. For instance, total $\mathrm{N}$ excretion rates of 8 to 10 -g fingerling rainbow trout are about 8-fold higher (Lauff and Wood 1996) than the rates for the 2- to 3-g ammocoetes studied here. Further, larval rainbow trout have total nitrogenous waste excretion rates (Wright et al. 1995) that are 30 times higher than ammocoetes. These interspecific differences may be explained by the ammocoete's very low metabolic rate, which accompanies their relatively sedentary burrow-dwelling life style (Potter and Rogers 1972).

\section{The mechanism of urea production}

The absence of significant CPSase III activity in the liver of ammocoetes suggests that this enzyme is absent or inactive during the larval period of the sea lamprey's life cycle. Thus, this observation lends no support to Griffith's (1991) hypothesis that the OUC enzymes leading to arginine synthesis were expressed in the "ammocoete-like" larvae of ancestral agnathans, to supplement a protein-deficient diet in their freshwater-stream habitat. Since the remaining enzymes of the OUC were detected in the liver of ammocoetes, albeit at low levels (Table 1), it is premature to suggest that the OUC is not active in other life stages or even in other tissues of the sea lamprey. Indeed, the full complement of OUC enzymes are active in embryonic and larval teleosts (Rice and Stokes 1974; Dépêche et al. 1979; Wright et al. 1995), and OUC enzymes have been detected in the intestine and muscle of several teleosts (Felskie et al. 1998).

Read (1968) detected significant CPSase activity in the liver of Pacific lampreys, which raised the possibility that this animal had the potential to produce urea via the OUC. Unfortunately, there is little additional support for this hypothesis because other key OUC enzymes, including ornithine carbamoyl transferase, were not detected by Read (1968). In addition, it is not clear if Read (1968) detected CPSase III activity in the Pacific lamprey, because, unlike the present study, CPSase II activity was not inhibited using uridine triphosphate (Anderson 1995).

The 3-fold greater urea excretion rates observed during exposure to high external levels of ammonia indicate that there were modest increases in urea production by ammo- 
coetes. Although the goal of these experiments was to stimulate the activity of OUC enzymes, these enzymes were unaffected by high external levels of ammonia, with one exception. Arginase activity doubled in the animals subjected to high external levels of ammonia, but it seems unlikely that this small increase would have influenced urea production and excretion significantly. Further, although arginase promotes the hydrolysis of dietary arginine to form urea (Mommsen and Walsh 1991), it is also unlikely that this was a source of significant urea production, because these animals were not fed in the 7-10 d preceding these experiments.

Although arginase activities were relatively low compared with the gulf toadfish and other fishes such as the tilapia (Wright 1993), the levels measured here were comparable to levels extrapolated from Read's (1968) data on migrating Pacific lamprey. In fact, higher arginase activity would make it difficult for ammocoetes to retain arginine, which is an essential amino acid in the diet of most fishes (Mommsen and Walsh 1991).

The present data demonstrate for the first time, that at least one agnathan has the biochemical machinery to produce urea using uricolysis. The absence of significant uricolytic enzyme activity in the liver of the hagfish (Myxine glutinosa; Read 1975) and the river lamprey (Florkin and Duchâteau 1943) led to the general conclusion that agnathans lack the enzymatic machinery to produce urea by this route. Adult lamprey were the focus of the latter study, however, in which rates of uricolysis could have been declining. The very low urea excretion rates of adult Pacific lamprey (Read 1968) and spawning sea lampreys (M.P. Wilkie and J.H. Youson, unpublished data) support this conclusion.

The activity of allantoicase, which converts allantoic acid to urea in the final step of uricolysis, was comparable to activity levels measured in the tilapia (O. niloticus; Wright 1993) and to the lower range of activities reported by Goldstein and Forster (1965) for 20 other teleost species. The activities of the remaining enzymes, uricase and allantoinase, were relatively low compared with those in other fishes (e.g., Goldstein and Forster 1965; Brown et al. 1966; Wright 1993), however. Once again, the low metabolic rate of ammocoetes possibly explains these observations, but the design and function of the ammocoete liver also differs from that of teleosts. A noteworthy difference is that peroxisomes of classical structure are inconspicuous in the liver of larval lampreys (Youson 1993). Since peroxisomes are a major site of enzymes involved in uricolysis in teleosts (Hayashi et al. 1989), a paucity of peroxisomes might explain the relatively low activities of uricase and allantoinase in the ammocoete liver.

\section{Ammonia detoxification and internal storage}

For ammocoetes, the 96-h $\mathrm{LC}_{50}$ for total ammonia was $3 \mathrm{mmol} \cdot \mathrm{L}^{-1}$, equivalent to $100 \mu \mathrm{mol} \cdot \mathrm{L}^{-1} \mathrm{NH}_{3}$, which exceeds that of many freshwater teleosts. This value is about 3-fold greater than the $\mathrm{NH}_{3} \mathrm{LC}_{50}$ values typically reported for salmonids and is within the range of values reported for fishes that are more ammonia tolerant, such as the fathead minnow (Pimephales promelas) and blue gill (Lepomis macrochirus) (United States Environmental Protection Agency 1985). Relatively stable blood lactate and glucose concentrations indicate that high external levels of ammonia had no major effect on the general physiology of the ammocoetes. Further, despite a large buildup of internal ammonia, the experimental ammocoetes did not exhibit the hyperactivity normally associated with the onset of ammonia toxicity (Arillo et al. 1981).

The blood total ammonia concentration measured in ammocoete plasma during exposure to $2 \mathrm{mmol} \cdot \mathrm{L}^{-1}$ total ammonia was $2000 \mu \mathrm{mol} \cdot \mathrm{L}^{-1}$, which is about 2 -fold higher than levels associated with mortality in salmonid fishes (Lumsden et al. 1993; Knoph and Thorud 1996). This tolerance may have been related to high activities of brain GS, which protects the central nervous system from ammonia's neurotoxic effects by promoting the conversion of $\mathrm{NH}_{3}$ and glutamate into less toxic glutamine (Mommsen and Walsh 1991). In fact, in ammocoetes, brain GS activities were 50- to 100fold higher than activities measured in the liver, intestine, and muscle. Although GS activity was $10 \%$ higher in the brains of animals subjected to high external levels of ammonia, it is doubtful whether such a marginal increase in enzyme activity would confer a large increment of additional protection against ammonia.

Under control (resting) conditions, the intramuscular ammonia concentration of trout is severalfold higher than plasma levels, owing to the presence of electrochemical gradients that favour plasma to muscle $\mathrm{NH}_{4}{ }^{+}$loading (Wright and Wood 1988; Wilkie and Wood 1995). Similarly, ammonia levels in muscle were about 3-fold higher than those in blood in ammocoetes under control conditions, but this was also true following exposure to high external levels of ammonia, when muscle ammonia concentrations approached $6 \mathrm{mmol} \cdot \mathrm{L}^{-1}$. This ability of the muscle to act as an ammonia reservoir may help to minimize circulating-ammonia levels and therefore may protect the ammocoete's nervous system from ammonia's neurotoxic effects.

\section{Conclusions}

Owing to their ancient origins, lampreys are considered modern representatives of the original jawless fishes (Forey and Janvier 1993). Accordingly, it has been proposed that the burrow-dwelling and suspension-feeding life style of ammocoetes may resemble that of some of the early jawless vertebrates (Griffith 1991). The presence of detectable uricolytic enzyme activity in the ammocoete liver suggests that some early vertebrates relied on the breakdown of uric acid to produce and excrete nitrogenous wastes as urea. Based on the detection of CPSase III in many teleosts, albeit at trace levels, several authors have proposed that an active OUC was also present in the earliest jawless vertebrates (Mommsen and Walsh 1989; Griffith 1991). At present, the absence of significant liver CPSase III activity in the ammocoete liver fails to support this hypothesis, but the possibility that OUC enzymes are expressed in other tissues and (or) life stages of the sea lamprey deserves further investigation.

\section{Acknowledgements}

We express our gratitude to Dr. John Holmes for his expert advice and help with the collection and dissection of ammocoetes. We are also grateful to J. Paupe, W. Anderson, R. Manzon, L. Manzon, S.G. Lund, and S.L. Swindell for their excellent technical assistance. K. Davidson's help col- 
lecting ammocoetes in New Brunswick is also gratefully acknowledged. This study was supported by a National Science Foundation research grant (IBN-9507239) to P.J.W and by Natural Sciences and Engineering Research Council of Canada research grants to J.H.Y. and M.P.W.

\section{References}

Anderson, P.M. 1995. Urea cycle in fish: molecular and mitochondrial studies. In Fish Physiology. Vol. 14. Cellular and molecular approaches to fish ionic regulation. Edited by C.M. Wood and T.J. Shuttleworth. Academic Press, New York. pp. 57-83.

Arillo, A., Margiocco, C., Melodia, F., Mensi, P., and Schenone, G. 1981. Ammonia toxicity mechanisms in fish: studies on rainbow trout (Salmo gairdneri Rich.). Ecotoxicol. Environ. Saf. 5: 316-328.

Barber, M.L., and Walsh, P.J. 1993. Interactions and acid-base status and nitrogen excretion and metabolism in the ureogenic teleost, Opsanus beta. J. Exp. Biol. 185: 87-105.

Bergmeyer, H.L. 1983. Methods of enzymatic analysis. Academic Press, New York.

Brown, G.W., and Brown, S.G. 1985. On urea formation in primitive fishes. In Evolutionary biology of primitive fishes. Edited by R.E. Foreman, A. Gorbman, J.M. Dodd, and R. Olsson. NATO Advanced Research Workshop. Plenum Press, London and New York. pp. 321-337.

Brown, G.W., Jr., James, J., Henderson, R.J., Thomas, W.N., Robinson, R.O., Thompson, A.L., Brown, E., and Brown, S.G. 1966. Uricolytic enzymes in liver of the Dipnoan Protopterus aethiopicus. Science (Washington, D.C.), 153: 1653-1654.

Crocker, C.L. 1967. Rapid determination of urea nitrogen in serum or plasma without deproteinization. Am. J. Med. Technol. 33: 361-365.

Cvancara, V.A. 1969. Comparative study of uricase activity in freshwater teleosts. Comp. Biochem. Physiol. 28: 725-732.

Dépêche, J., Gilles, R., Daufresne, S., and Chaipello, H. 1979. Urea content and urea production via the ornithine-urea cycle during the ontogenic development of teleost fishes. Comp. Biochem. Physiol. A, 63: 51-56.

Felskie, A.K., Anderson, P.M., and Wright, P.A. 1998. Expression and activity of carbamoyl-phosphate synthetase-III and ornithine urea cycle enzymes in various tissues of 4 fish species. Comp. Biochem. Physiol. B, 119: 355-364.

Florkin, M., and Duchâteau, G. 1943. Les formes du systéme enzymatique de l'uricolyse et l'evolution du catabolisme purique chez les animaux. Arch. Int. Physiol. LIII: 267-307.

Forey, P., and Janvier, P. 1993. Agnathans and the origin of jawed vertebrates. Nature (London), 361: 129-134.

Goldstein, L., and Forster, R.P. 1965. The role of uricolysis in the production of urea by fishes and other aquatic vertebrates. Comp. Biochem. Physiol. 14: 567-576.

Griffith, R.W. 1991. Guppies, toadfish, coelacanths and frogs: a scenario for the evolution of urea retention in fishes. Environ. Biol. Fishes, 32: 199-218.

Hayashi, S., Fujiwara, S., and Noguchi, T. 1989. Degradation of uric acid in fish liver peroxisomes. J. Biol. Chem. 264: 3211-3215.

Holmes, J.A., and Youson, J.H. 1994. Fall condition factor and temperature influence the incidence of metamorphosis in sea lampreys, Petromyzon marinus. Can. J. Zool. 72: 1134-1140.

Knoph, M.B., and Thorud, K. 1996. Toxicity of ammonia to Atlantic salmon (Salmo salar) in sea water-effects on plasma osmality, ion, ammonia, urea and glucose levels and haematological parameters. Comp. Biochem. Physiol. A 113: 375-381.

Lauff, R.F., and Wood, C.M. 1996. Respiratory gas exchange, nitrogenous waste excretion, and fuel usage during aerobic swimming in juvenile rainbow trout. J. Comp. Physiol. B, 166: $501-509$.

Lumsden, J.S., Wright, P.A., Derksen, J., Byrne, P.J., and Ferguson, H.W. 1993. Paralysis in farmed Arctic char (Salvelinus alpinus) associated with ammonia toxicity. Vet. Rec. 133: 422-423.

Mecke, D. 1985. L-glutamine, colorimetric method with glutamine synthetase. In Methods of enzymatic analysis. Vol. 8. Edited by H.U. Bergmeyer. VCH Verlagsgesellschaft $\mathrm{mbH}$, Weinheim. pp. 364-369.

Mommsen, T.P., and Walsh, P.J. 1989. Evolution of urea synthesis in vertebrates: the piscine connection. Science (Washington, D.C.), 243: $72-75$.

Mommsen, T.P., and Walsh, P.J. 1991. Urea synthesis in fishes: evolutionary and biochemical perspectives. In Biochemistry and molecular biology of fishes. Vol. 1. Edited by P.W. Hochachka and T.P. Mommsen. Elsevier Science Publishers, New York. pp. 137-163.

Potter, I.C., and Rogers, M.J. 1972. Oxygen consumption in burrowed and unburrowed ammocoetes of Lampetra planeri (Bloch). Comp. Biochem. Physiol. A, 41: 427-432.

Randall, D.J., Wood, C.M., Perry, S.F., Bergman, H., Maloiy, G.M.O., Mommsen, T.P., and Wright, P.A. 1989. Urea excretion as a strategy for survival in a fish living in a very alkaline environment. Nature (Lond.), 337: 165-166.

Read, L.J. 1968. A study of ammonia and urea production and excretion in the fresh-water-adapted form of the Pacific lamprey (Entosphenus tridentatus). Comp. Biochem. Physiol. 26: 455-466.

Read, L.J. 1975. Absence of ureogenic pathways in the liver of the hagfish Bdellostoma cirrhatum. Comp. Biochem. Physiol. B, 51: 139-141.

Rice, S.D., and Stokes., R.M. 1974. Metabolism of nitrogenous wastes in the eggs and alevins of rainbow trout, Salmo gairdneri Richardson. In The early life history of fish. Edited by J.H.S. Blaxter. Springer-Verlag, New York. pp. 325-337.

Robertson, J.D. 1954. The chemical composition of the blood of some aquatic chordates of the Tunicata, Cyclostomata, and Osteichthyes. J. Exp. Biol. 31: 424-442.

Saha, N., and Ratha, B.K. 1989. Comparative study of ureogenesis in freshwater, air-breathing teleosts. J. Exp. Zool. 252: 1-8.

Saha, N., and Ratha, B.K. 1994. Induction of ornithine-urea cycle in a freshwater teleost, Heteropneustes-fossilis, exposed to high concentrations of ammonium-chloride. Comp. Biochem. Physiol. B, 108: 315-325.

Smith, H.W. 1929. The excretion of ammonia and urea by the gills of fish. J. Biol. Chem. 81: 727-742.

Sprague, J.B. 1969. Measurement of pollutant toxicity to fish. I. Bioassay methods for acute toxicity. Water Res. 3: 793-821.

Sutton, T.M., and Bowen, S.H. 1994. Significance of organic detritus in the diet of larval lampreys in the Great Lakes basin. Can. J. Fish. Aquat. Sci. 51: 2380-2387.

United States Environmental Protection Agency. 1985. Ambient water quality criteria for ammonia-1984. United States Environmental Protection Agency Publ. No. EPA 440/5-85-001, Washington, D.C.

Walsh, P.J. 1996. Purification and properties of hepatic glutamine synthetases from the ureotelic Gulf toadfish, Opsanus beta. Comp. Biochem. Physiol. B, 115: 523-532.

Walsh, P.J., Danulat, E., and Mommsen, T.P. 1990. Variation in urea excretion in the Gulf toadfish Opsanus beta. Mar. Biol. (Berl.), 106: 323-328.

Wilkie, M.P., and Wood, C.M. 1991. Nitrogenous waste excretion, acid-base regulation, and ionoregulation in rainbow trout 
(Oncorhynchus mykiss) exposed to extremely alkaline water. Physiol. Zool. 64: 1069-1086.

Wilkie, M.P., and Wood, C.M. 1995. Recovery from high pH exposure in rainbow trout: white muscle ammonia storage, ammonia washout and the restoration of blood chemistry. Physiol. Zool. 86: $379-401$.

Wilkie, M.P., Wright, P.A., Iwama, G.K., and Wood, C.M. 1993. The physiological responses of the Lahontan cutthroat trout (Oncorhynchus clarki henshawi), a resident of highly alkaline Pyramid Lake, to challenge at pH 10. J. Exp. Biol. 175: 173-194.

Wilkie, M.P., Simmons, H.E., and Wood, C.M. 1996. Physiological adaptions of rainbow trout to chronically elevated water $\mathrm{pH}$ $(\mathrm{pH}=9.5)$. J. Exp. Zool. 274: 1-14.

Wright, P.A. 1993. Nitrogen excretion and enzyme pathways for ureagenesis in freshwater tilapia (Oreochromis niloticus). Physiol. Zool. 66: 881-901.
Wright, P.A. 1995. Nitrogen excretion: three end-products, many physiological roles. J. Exp. Biol. 198: 273-281.

Wright, P.A., and Wood, C.M. 1988. Muscle ammonia stores are not determined by pH gradients. Fish Physiol. Biochem. 5: 159-162.

Wright, P.A., Felskie, A., and Anderson, P.M. 1995. Induction of ornithine-urea cycle enzymes and nitrogen metabolism and excretion in rainbow trout (Oncorhynchus mykiss) during early life stages. J. Exp. Biol. 198: 127-135.

Youson, J.H. 1980. Morphology and physiology of lamprey metamorphosis. Can. J. Fish. Aquat. Sci. 37: 1687-1710.

Youson, J.H. 1993. Biliary atresia in lampreys. In Advances in veterinary science and comparative medicine. Edited by C.E. Cornelius. Academic Press, San Diego. pp. 197-255. 